\title{
What I Learn from Theatregoing: Review Haiku
}

\author{
Monica Prendergast ${ }^{1}$ \\ University of Victoria \\ mprender@uvic.ca
}

\begin{abstract}
A haiku suite of theatre reviews and reflection on application to practice as drama educator and scholar.
\end{abstract}

Keywords: poetic inquiry, theatre reviews, reflective practice, haiku

\footnotetext{
${ }^{1}$ Biographical statement: Monica Prendergast is Associate Professor of drama/theatre education at the University of Victoria. She has published her poetic inquiry widely including two edited collections and two special issues. Monica also researches aspects of drama/theatre curriculum and pedagogy. Her latest project involves the development and implementation of a new performance studies curriculum for secondary students.
} 
Theatre is the most social of art forms, yet sharing the experience of theatre is often quite private. We might discuss the play we have seen for a few minutes with whomever has come with us and then life moves on. If we see a show alone (as I often do when travelling) our response is a soliloquy; a silent dialogue with ourselves. We may read, see or hear a review and allow the critic his or her privileged public monologue that is rarely responded to or challenged. Here, I invite you to share your responses to any or all of these review haiku created in response to theatre productions I have seen in Toronto, London, Stratford-UponAvon and New York in the past two to three years.

I have been a freelance theatre reviewer for the Canadian Broadcasting Corporation since 2006. For over nine years now I have shared my responses to local theatre and opera productions with listeners of CBC Radio's On the Island morning program. And last year I was invited to begin writing a monthly theatre column for a local news and arts magazine here in Victoria, British Columbia (www.focusonline.ca). I also travel to academic conferences once or twice a year in large urban centres, which allows me to go to the theatre. Between 2013 and now, on top of the average maybe two-dozen productions I see in Victoria each season, I have also seen seven shows in Toronto, eleven in New York, eight in London and two at the Royal Shakespeare Company in Stratford. This adds up to a total of around fifty productions from the fall of 2013 to the summer of 2015.

As a result of this travel and local community engagement activities, it seems worthwhile to consider if, and if so in what ways, my commitment to theatregoing and reviewing has affected my sense of myself as a researcher in the fields of drama/theatre education and applied drama/theatre. I am a theatre educator; so the question unfolds, what does theatre teach me? "When the play ends, what remains?" (Bharucha, 2011, p. 366). What remains from my theatre attendance that informs my thinking about the art form? How might this thinking in turn inform my research and teaching? What have these fifty shows left behind as residue I can locate in the archive of an audience member's memory and put to good use (Blau, 1995; Prendergast, 2004)? What begins?

Another hat I wear is that of an arts-based researcher. I find standardized research difficult to both read and write; somewhat soul-flattening in fact. Artsbased research has offered me creative possibilities for rendering my inquiries in artful ways, and I have become very drawn to poetic approaches over time. For me, poetic inquiry offers a counterbalance in its (mostly) solitary and contemplative practice, to the deeply social practices of drama teaching, theatremaking and spectatorship. Thus, this contribution is shaped as a haiku suite. I have found the very constrained form of haiku, seventeen syllables, to be an excellent way to crystallize my thinking in creative analytic practice (Richardson $\&$ St. Pierre, 2005). The concentration of the form also allows, I believe, a reader to catch what is being communicated in both an efficient and potentially 
efficacious manner (see Prendergast, 2004, 2016; Prendergast et al., 2009). Poet Lawrence Ferlinghetti (1975/2007) says that a poem is "the shortest distance between two humans" (p. 40). If one or more of these theatre reviews ${ }^{2}$ haiku spark an arc of connection between my reader and myself then this inquiry will be (for me) a success.

The Double written/directed by Viktor Lukawski, Arif Mirabdolbaghi \& Adam Paolozza (an adaptation of the book by Fyodor Dostoyevsky) BND/Tarragon Theatre, Toronto (October 2013)

a double bass plays

our hero's shadow shadows him

mirrored nightmare self

Farther West by John Murrell (remount of 1982 play)

Soulpepper Theatre, Toronto (October 2013)

sometimes a design

is better than the play

actors' hard work fails

Round and Round the Garden (The Norman Conquests, Part 3) by Alan Ayckbourn

Soulpepper Theatre, Toronto (October 2013)

in the round watching good players in light fare we chuckle not laugh

\section{Desh created and performed by Akram Khan Canadian Stage Theatre, Toronto (November 2013)}

how the body, sound and light can say more than words:

a playwright's despair

\footnotetext{
${ }^{2}$ I have limited my reviews to shows seen in Toronto, London, Stratford and New York as they are more likely to be familiar to or may have been seen also by readers.
} 


\section{Dirty Butterfly by Debbie Tucker Green Bound to Create/Obsidian Theatre, Toronto (November 2013)}

an abused woman

drips red sand as blood onstage

shakes us all awake

Fun Home by Lisa Kron and Jeanine Tesori (adapted from Alison Bechdel's graphic memoir)

Public Theatre, New York (December 2013)

closeted father

and his queer daughter struggle

this home is not fun

Twelfth Night by William Shakespeare

London's Globe Theatre, New York (December 2013)

we watch all these men

in original practice

fall in love with love

\section{A Midsummer Night's Dream by William Shakespeare}

Theatre for a New Audience, New York (December 2013)

spouse and sons thumbs-down

this choice, not buying Taymor's

design-driven show

Machinal by Sophie Treadwell (remount of 1928 play)

Roundabout Theatre, New York (December 2013)

so trapped in her life

a husband killer (true story)

is executed 
The Pajama Game by George Abbott and Richard Bissell

Shaftesbury Theatre, London (July 2014)

a B musical

done in an A plus way

sexist dated fun

Wolf Hall (Part 1) by Mike Poulton (adapted from the novels by Hilary Mantel)

Royal Shakespeare Company at Aldwych Theatre, London (July 2014)

such storytelling

the sweep of history yet

how petty, human

1984 by Robert Icke and Duncan Macmillan (adapted from the novel by George Orwell)

Nottingham Playhouse/Headlong at Almeida Theatre, London (July 2014)

lovers discovered

set explodes before our eyes

white cell, pain, red blood

Once by Enda Walsh, Glen Hansard and Marketa Irglova

Phoenix Theatre, London (July 2014)

actor/musicians

tell this simple love story

leave me here, weeping

Medea by Euripides (adapted by Ben Powers)

National Theatre, London (July 2014)

betrayed and broken

this enraged merciless mother

kills her babes (we grieve) 
A Small Family Business by Alan Ayckbourn (remount of 1987 play) National Theatre, London (July 2014)

large cast, large canvas

family taken by greed:

the present foretold?

Great Britain by Richard Bean

National Theatre, London (July 2014)

'Ripped from the Headlines'

News of the World scandal shared

delicious satire

Elephantom by Ben Powers (adapted from the book by Ross Collins) National Theatre, London (July 2014)

witness their delight

with sound, music, mime, puppets:

a young child's first play

The Two Gentlemen of Verona by William Shakespeare Royal Shakespeare Company, Stratford-Upon-Avon (July 2014)

two boys, good and bad

Julia bares her bound breasts

shames her faithless man

The White Devil by John Webster

Royal Shakespeare Company, Stratford-Upon-Avon (July 2014)

revenge tragedy

everybody dies here

murderous mayhem

Ghosts by Henrik Ibsen (adapted by Richard Eyre)

Brooklyn Academy of Music, New York (May 2015)

flawless production

(design, directing, and acting)

sunrise and slow fade 


\section{Airline Highway by Lisa D'Amour Manhattan Theatre Club, New York (May 2015)}

motel family

in New Orleans hosts a party

down and out, dancing

The Curious Incident of the Dog in the Night-Time by Simon Stephens (adapted from the novel by Mark Haddon)

Ethel Barrymore Theatre, New York (May 2015)

I sit in back row

yet am pulled deeply into

this boy's story (yes!)

The King \& I by Richard Rodgers and Oscar Hammerstein

Vivian Beaumont Theater, Lincoln Center, New York (May 2015)

if aliens ask

"What is a musical here?"

I would show them this

Zorba! by Joseph Stein, John Kander and Fred Ebb

City Center Encores series, New York (May 2015)

to be seen and heard

educated audience

stays for the talkback

Hand to God by Robert Askins

Booth Theatre, New York (May 2015)

so funny at first

darker and deeper it goes

into puppet hell

What do these haiku tell me about my experiences? First, I note how many dramatic adaptations I saw. This seems to be a recent trend, led by the National Theatre's successes with War Horse, His Dark Materials, and Curious Incident (among others), Nottingham Playhouse/Headlong's 1984 and the RSC's 
Wolf Hall. It also speaks to my own theatrical tastes for a substantial story that a literary adaptation usually guarantees. I saw three Shakespeare productions that were chosen in part due to my profession; how can one love theatre and not The Bard? That said, there are five musicals in this suite, all of which succeeded on many levels. I am also drawn to new plays that tell me what is on the horizon, as with Airline Highway, Fun Home, Great Britain and Hand to God. I clearly have a British bias when I choose shows from England when in New York and Toronto! This is my heritage as I am British-born, although long ago immigrated to Canada. I often consider the quality of both writing and performance to be higher in British productions. As I see this bias more clearly, it allows me to make a correction in my colonial thinking around perhaps being overly critical at times of Canadian or American fare as somewhat lesser-than.

And to respond to Rustom Barucha's (2011) important question, "What remains?" What have I archived here as fragments of memory in performance? As an actor myself, I always respond to the work of a performer first. An actor's vulnerability, risk-taking, endurance, honesty, physicality and technical prowess are what stay with me. The aura of a strong performer cannot be experienced outside of the live encounter of theatre and performance. I go to National Theatre Live screenings religiously and thank god for them. But I cannot equate seeing these plays on screen with their liveness. It is fascinating to me that at the end of an NT Live screening the audience often applauds along with the one in London (or wherever the show originates). That useless applause feels a bit sad, as if we want to be heard, included in the circle, but cannot be. To see a fine performer in full flight is the core reason I go to the theatre.

Next in importance for me is the text of a show, whether verbal or mostly nonverbal (the latter as in Desh and Elephantom). A good play, performance, or dramatic adaptation allows me to enter fully into a dramatic world and to explore it through dialogue, tension, action, conflict and resolution. Well-wrought monologues and scenes extend our understanding of the possibilities of language and communication. Design is the third element of importance. I would place design ahead of direction as I consider good direction to be almost invisible; a production that tips into being over-directed can irk me (as in Julie Taymor's Dream, which was also over-designed at the expense of the ensemble). But excellent design that supports the production in integral ways is one of the great pleasures of theatre. The design elements of set, costumes, props, lighting and sound in many of these shows stay with me as residue. How beautifully staged The King and I and Ghost were so I could sit back and let them wash over me. How effectively video technology supported the storytelling in Curious Incident and Desh. How, if a play is failing me, my attention moves to considering design, as in Farther West and Airline Highway, as a tactic for me to value and appreciate what I am taking in.

To conclude, I consider theatregoing to be an essential part of my research, teaching and scholarship. I take my drama education students to the 
theatre every term so as to ensure that they see the continuum of practice from improvised roleplay in a Kindergarten class to a full professional production. My reviews and columns about local theatre are a contribution to my community that feel vital to me. Finally, I have reflected on a selection of my recent theatregoing experiences that I hope may prompt readers to do the same. What is it about the theatre that has called out to each of us and keeps us in its thrall? What are its triumphs and failures in our eyes? Where is the art form going, and how are the next generation of theatre artists and theatregoers taking us there (Tannahill, 2015)? These are the questions that engage me. 


\section{References}

Bharucha, R. (2011). Problematising applied theatre: A search for alternative paradigms. Research in Drama Education: Journal of Applied Theatre and Performance, 16(3), 365-384.

Blau, H. (2004). The audience. Baltimore, MD: Johns Hopkins.

Ferlinghetti, L. (1975/2007). Poetry as insurgent art. New York: New Directions.

Prendergast, M. (2016). Found haiku from Laurel Richardson's "Writing: A method of inquiry". In J. White (Ed.), Permission: The international interdisciplinary impact of Laurel Richardson's work (pp. 123-126). Rotterdam, NL: Sense.

Prendergast, M. (2004). "Shaped like a question mark": Found poems from Herbert Blau's The Audience. Research in Drama Education, 9(1), 73-92.

Prendergast, M., Gouzouasis, P., Leggo, C., Irwin, R. \& Grauer, K. (2009). A haiku suite: The importance of music-making in the lives of secondary school students. Music Education Researcher, 11(3), 303-317.

Richardson, L. \& St. Pierre, E. (2005). Writing: A method of inquiry. In N. K. Denzin \& Y. S. Lincoln (Eds.), SAGE Handbook of Qualitative Research ( ${ }^{\text {rd }}$ ed.), (pp. 959-978). Thousand Oaks, CA: SAGE.

Tannahill, J. (2015). Theatre of the unimpressed. Toronto, ON: Coach House. 